\title{
Thermal Properties of Some Turkish Peloids and Clay Minerals for Their Use in Pelotherapy
}

\author{
M. Çelik Karakaya ${ }^{1 *}$, N. Karakaya ${ }^{1}$, H. Cingilli Vural ${ }^{2}$ \\ ${ }^{1}$ Selçuk Üniversitesi Mühendislik Fak. Jeoloji Mühendisliği Bölümü, Konya, Turkey \\ ${ }^{2}$ Faculty of Medicine, Necmettin Erbakan University, Konya, Turkey \\ Email: *mcelik@selcuk.edu.tr
}

How to cite this paper: Karakaya, M.Ç., Karakaya, N. and Vural, H.C. (2016) Thermal Properties of Some Turkish Peloids and Clay Minerals for Their Use in Pelotherapy. Geomaterials, 6, 79-90.

http://dx.doi.org/10.4236/gm.2016.64007

Received: September 29, 2016

Accepted: October 24, 2016

Published: October 27, 2016

Copyright $\odot 2016$ by authors and Scientific Research Publishing Inc. This work is licensed under the Creative Commons Attribution International License (CC BY 4.0).

http://creativecommons.org/licenses/by/4.0/

\begin{abstract}
The thermal properties such as specific heat capacity and heat dissipation of peloids play an important role in therapeutic applications. Therefore, these properties were determined on the peloids samples taken from spas where peloid applications are used in Turkey. In addition, some pure clay minerals were investigated to determine their suitability as possible constituents of therapeutic peloids and to make recommendations for preparing the most usable peloids for thermal therapy. For this aim, the mineralogical and thermal properties of samples were investigated using X-ray diffraction (XRD) and Differential Scanning Calorimeter (DSC). The mineralogical compositions of the peloid samples are not homogenous, and their clay mineral content is approximately $60 \%$, and the most abundant clay mineral is calcium montmorillonite. The cooling time of peloids are between 20 and 25 minutes, which is suitable for therapy and thus these peloids are suitable for using in health problems requiring heat treatment. The samples have favorable heat dissipation capacity and partially cooling kinetics. Specific heat capacity of the peloid samples is partially appropriate for heat therapy and these values range from 0.60 to $1.41 \mathrm{~J} / \mathrm{g} .{ }^{\circ} \mathrm{C}$, and partially high in peloids with high smectite content. The pure sepiolite samples have higher heat dissipation properties than those of other clay minerals especially illites and kaolinites. Ca-montmorillonite and kaolinite have the lowest specific heat values while sepiolite samples have higher values. Sepiolite and partly $\mathrm{Na}-\mathrm{Ca}$-montmorillonite are more appropriate than the other studied clay minerals as a peloid constituent especially for therapy of musculoskeletal pain.
\end{abstract}

\section{Keywords}

Clay Minerals, Health, Heat Dissipation, Peloid, Pelotherapy, Specific Heat 


\section{Introduction}

Thermal therapies are beneficial in treatment of great diversity of acute and chronic rehabilitative problems. In spa therapy, in addition to bathing in hot waters, peloid applications known as pelotherapy is also carried out in Turkey and around the world. The clay mineral-rich material known as peloid and/or thermal mud is matured by mostly thermal and occasionally natural waters, and sometimes additional materials such as paraffin, humic matter are added. The peloids are preferred in treatment of some diseases because of keeping heat in longer period than hot water. It has been shown that the thermal properties of peloids can be used to treat various joint problems, breakages, dislocations, vasculopathy and dermatological illnesses [1]. Clay mineralrich peloids are mostly used for thermal therapy for chronic rheumatic inflammation, sports traumas and dermatological problems [2].

In pelotherapy applications, the temperature of prepared peloid is required to be $5^{\circ} \mathrm{C}$ - $10^{\circ} \mathrm{C}$ above body temperature, and it is appropriate to maintain this temperature within 15 to 20 minutes before reaching body temperature. The temperature of a peloid needs to be $40^{\circ} \mathrm{C}-45^{\circ} \mathrm{C}$ cool gradually and its temperature between $40^{\circ} \mathrm{C}-60^{\circ} \mathrm{C}$ retain within 20 - 30 minutes during the therapy [3].

The peloid is applied as a $1-2 \mathrm{~cm}$ paste over the whole body or specific areas by means of a mask, bandage or by plastering about 15 days in two times repeatedly. The peloid is covered with an impermeable covering to help it retain its heat as required for the duration of the therapy. That enables the hot mixture to have a greater effect on the skin and consequently on the musculo-skeletal system. Peloids are useful heat therapy those purposes are effective in reducing pain and treating musculo-skeletal problems, e.g. fibromyalgia, bursitis. Thermal therapy is useful for relieving pain in patients with rheumatic disease [4]. Combination of multidisciplinary treatment and repeated thermal therapy decreases the number of pain behavior in patients with chronic pain [5].

Peloids prepared from bentonite which have chemical and rheological properties such as high swelling potential, appropriate heat dissipation and operability properties can be suitable in pelotherapy [6]. In the above mentioned study, it is also explained that features of clay materials are important in determination of heat dissipation of clay pastes materials, and this researchers calculated theoretically heat dissipation capacity by using chemical and mineralogical composition. Reference [7] determined mineral types and mineral content and prepared various thermal waters of different compositions were added to the muds to formulate peloids. And above authors suggested that heat dissipation capacity with high smectite clays is higher, as they have a higher water content in comparison to other clay minerals, and that the rheological properties of the mud and its stickiness are important factors in the contact between skin and mud. The consistency of the peloid improves with the addition of Ca- and Mg-sulphate waters, but it decreases with other waters [8]. The importance of the heat dissipation, viscosity, oil absorption and rheological properties of the pastes prepared from the peloids is explained by [8]. The suitability of hot spring in therapy and use of various clay minerals (kaolinite, illite-smectite, smectite) is interrelated with grain size, low hardness index, 
rheological properties, high water dissipation capacity, cation exchange capacity and heat dissipation properties [9]. The heat dissipation capacity of peloids is directly related with the specific heat and, inversely, to their thermal conductivity [10].

Studies on peloid properties and use in Turkey are very limited in number. The first time mineralogical and chemical properties of some peloids were studied by [11]. Radioactive properties and potential health risk of the some peloids in Turkey was also carried out by [12] [13]. Apart from those studies, the heat dissipation and specific heat properties of (peloid) muds used for therapy and esthetics since ancient times have not been studied. This study aimed 1) to compare thermal properties of some clay minerals to peloids, 2) and to provide recommendations to improve the suitability of the peloids from 20 different spa centers, and 3) to determine their suitability of clay minerals as possible constituents of therapeutic peloids in health treatments.

\section{Materials and Methods}

Matured 20 peloid samples were taken from main spa centers in Turkey (Figure 1). After drying and sieving the samples, subsequently, they were homogenized, dried and pulverized for $5 \mathrm{~min}$ in a porcelain ball mill for mineralogical analyses. The pure clay minerals, with mineralogical and chemical properties previously defined in [14] and [15]-[18], were collected from different areas of Turkey. The mineralogical analyses of the samples were conducted on random and oriented samples (total fraction) $(<2 \mu \mathrm{m}$ clay-sized fractions) using X-ray diffraction (XRD) with CuKa radiation from $2^{\circ}-70^{\circ}$ $2 \theta$ at a scanning speed of $1^{\circ} 2 \theta / \mathrm{min}$. The mineral proportions were determined with the powder XRD patterns, according to the external standard method developed by [19] (Table 1). All samples were embedded as defined by [19] [20], and the representative peak intensities (I) of the minerals were normalized to those of the (104) reflection of dolomite. The $\mathrm{K}$ factor was determined for each mineral (including clays with peaks between $19^{\circ}$ and $20^{\circ} 2 \theta$ ) by weight in a 1:1 dolomite-mineral mixture as follows: $K=$ $I_{\text {dolomite }} / I_{\text {mineral }}$. The mineral percentages were calculated from the following Equation (1).

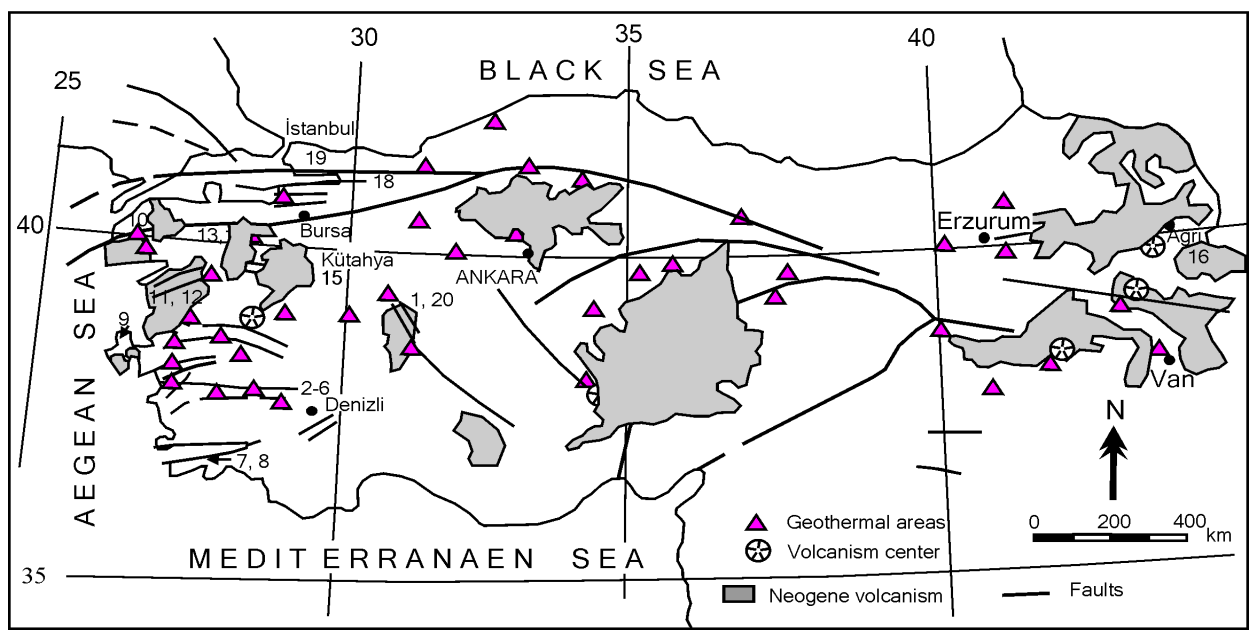

Figure 1. Location of the peloid samples. 
Table 1. Mineralogical composition (rare components were omitted) of the peloid samples.

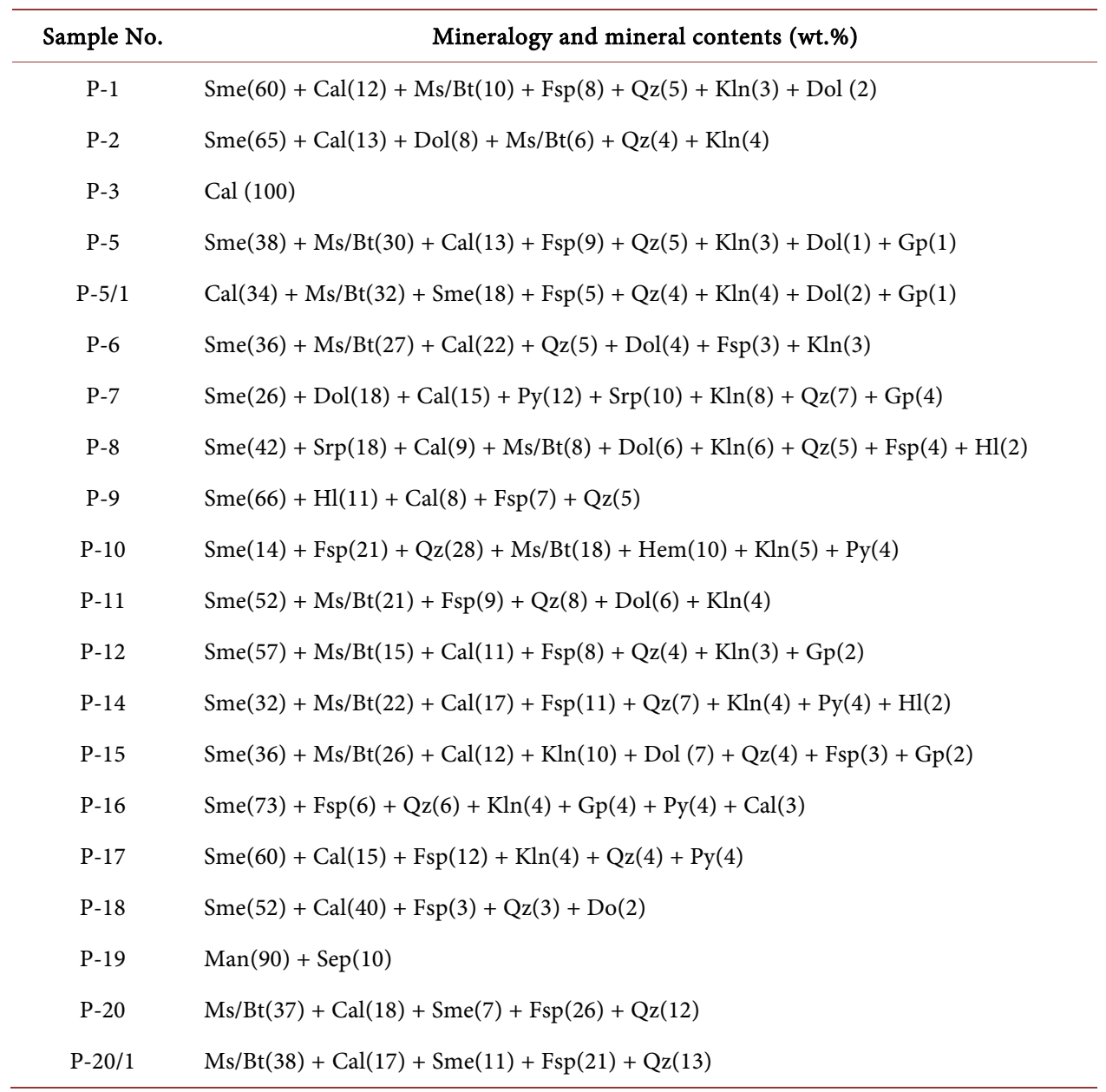

Note: Bt: Biotite, Cal: Calcite, Dol: Dolomite, Fsp: Feldspars, Gp: Gypsum, Hem: Hematite, Hl: Halite, Hyl: Halloysite, Ilt: Illite, Kln: Kaolinite, Man: Magnesite; Ms: Muscovite, Qz: Quartz, Sme: Smectite, Sep: Sepiolite, Srp: Serpentine, Py: Pyrite (abbreviations from [28]).

$\%$ of mineral a $=\left(100 \times K_{a} \times I_{a}\right) /\left(K_{a} \times I_{a}+K_{b} \times I_{b}+\cdots+K_{n} \times I_{n}\right)$

The accuracy of this method within $\pm 15 \%$.

After drying the peloid samples from the 20 hot springs in the study (at $50^{\circ} \mathrm{C}$ in an oven) they were ground to approximately $63 \mu \mathrm{m}$ size in an agate mortar. Methods of reference [2] [21] were used to prepare and measure the heat dissipation and specific heat capacity of the samples. The $50 \mathrm{~g}$ samples from the ground peloids were added to $40 \mathrm{ml}$ distilled water and heated at $70^{\circ} \mathrm{C}$ for 24 hours in a $125 \mathrm{ml}$ teflon container with a wall thickness of $5 \mathrm{~mm}$. The heated samples were placed in a covered thermostatic water bath set to $37.5^{\circ} \mathrm{C}$ (average body temperature), and temperature readings were taken every 30 seconds until the temperature of the water reached $37.5^{\circ} \mathrm{C}$ again (Figure 2).

Differential Scanning Calorimetry (DSC) was used to measure the specific heat capacities of the peloid and some pure clay samples. The samples were dried and prepared for their specific heat capacities were measured in a Netzsch STA 449 F3 DTA/TG/DSC device. The samples used were $63 \mu \mathrm{m}$ and dried at $50^{\circ} \mathrm{C}$, heat flow was 


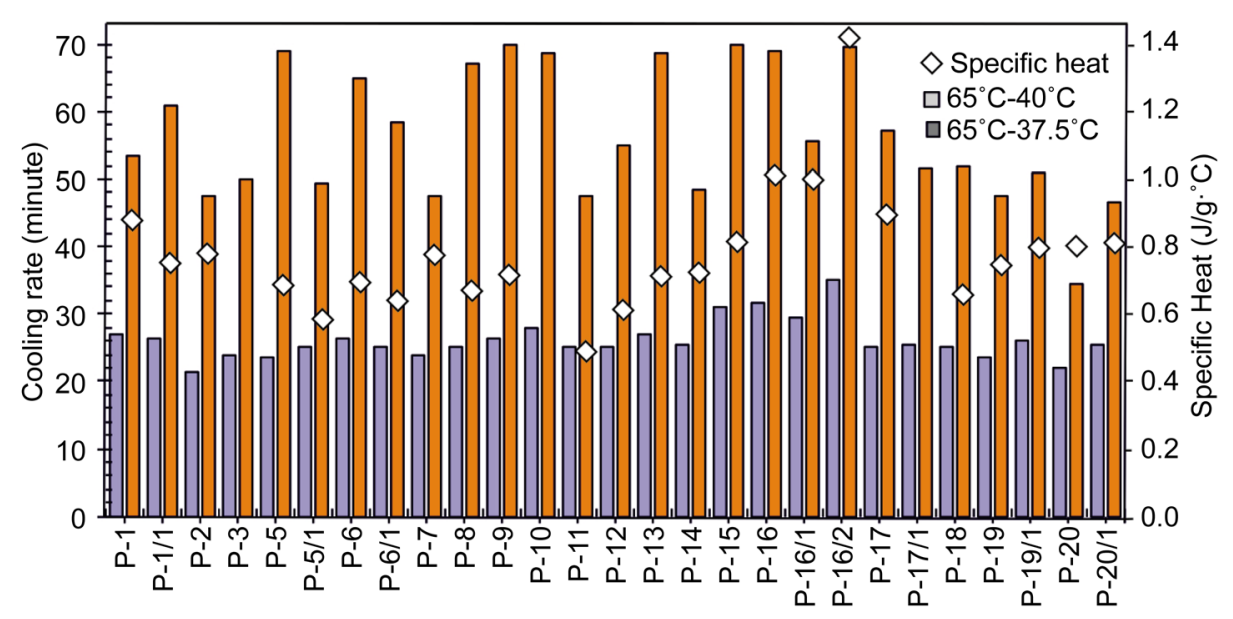

Figure 2. Heat retention and specific heat values of the peloid samples.

$10^{\circ} \mathrm{C} / \mathrm{min}$, and measurements were taken in an argon atmosphere at $20^{\circ} \mathrm{C}-200^{\circ} \mathrm{C}$ by Afyonkarahisar University. With this method, the energy released during sample heating, cooling or at a constant temperature can be recorded. It was seen as the most suitable method for measuring the heat flow of the DSC samples, as the reaction enthalpy is measured described as [22]. The energy released during the reaction was determined by integrating the DSC peaks. Heat diffusiveness of the all samples were determined by heating of the dried sample in a small teflon container $(100 \mathrm{ml})$ up to $65^{\circ} \mathrm{C}$ and measured the decrease of temperature to $35^{\circ} \mathrm{C}$ placed in thermally insulated water bath as described by [2].

\section{Results and Discussion}

Mineralogical composition of the peloids are generally similar and composed mainly of clay minerals, e.g., smectite, illite and illite-smectite, with partially of quartz and feldspar, some calcite, dolomite and amorphous silica, and rarely of kaolinite, halite, serpentine and gypsum (Table 1). The exception is sample P-19, which contains $90 \%$ magnesite and $10 \%$ sepiolite. The percentage of the clay minerals was frequently between $50 \%$ and $60 \%$, and the most abundant clay mineral was Ca-montmorillonite.

The crucial thermal parameters of a peloid in pelotherapy are heat dissipation and specific heat capacity. The material used in pelotherapy has slow heat conduction and high heat dissipation and therefore does not create the sudden heat problems seen in hot water baths. The effectiveness continues during the heat conduction phase. Pelotherapy requiring high heat conduction, dissipation and specific heat capacity, and pelotherapy is more effective than hot water therapy, because the process of heat flow maintain longer.

The heat dissipation and specific heat capacity of the peloids were determined. The duration of falling from $65^{\circ} \mathrm{C}$ to $40^{\circ} \mathrm{C}$ in temperature were determined which of the samples mineralogical compositions are established (Table 1 and Table 2). In all the peloid samples that do not display a homogenous composition from a mineral content perspective, temperatures between $65^{\circ} \mathrm{C}$ and $40^{\circ} \mathrm{C}$ were maintained for $20-30$ minutes, 
Table 2. Cooling rate of peloids samples and some pure clay minerals in some temperature ranges (in minutes).

\begin{tabular}{|c|c|c|c|c|c|}
\hline Sample No. & $65^{\circ} \mathrm{C}-40^{\circ} \mathrm{C}$ & $65^{\circ} \mathrm{C}-37.5^{\circ} \mathrm{C}$ & Sample No. & $65^{\circ} \mathrm{C}-40^{\circ} \mathrm{C}$ & $65^{\circ} \mathrm{C}-37.5^{\circ} \mathrm{C}$ \\
\hline P-1 & 27.0 & 53.5 & P-13 & 27.0 & 48.5 \\
\hline $\mathrm{P}-1 / 1$ & 26.5 & 51.0 & $\mathrm{P}-14$ & 25.4 & 48.5 \\
\hline $\mathrm{P}-2$ & 21.5 & 47.5 & P-15 & 31.0 & 50.0 \\
\hline $\mathrm{P}-3$ & 24.0 & 50.0 & $\mathrm{P}-16$ & 31.5 & 49.0 \\
\hline P-5 & 23.5 & 55.0 & P-16/1 & 29.5 & 45.5 \\
\hline $\mathrm{P}-5 / 1$ & 25.0 & 49.5 & P-16/2 & 35.0 & 49.5 \\
\hline P-6 & 26.5 & 55.0 & P-17 & 25.0 & 57.0 \\
\hline P-6/1 & 25.0 & 48.5 & $\mathrm{P}-17 / 1$ & 25.5 & 51.5 \\
\hline P-7 & 24.0 & 47.5 & P-18 & 25.0 & 52.0 \\
\hline P-8 & 25.0 & 47.0 & P-19 & 23.5 & 47.5 \\
\hline P-9 & 26.5 & 40.0 & P-19/1 & 26.0 & 51.0 \\
\hline P-10 & 28.0 & 48.5 & $\mathrm{P}-20$ & 22.0 & 34.5 \\
\hline P-11 & 25.0 & 47.5 & P-20/1 & 25.5 & 36.5 \\
\hline P-12 & 25.0 & 45.0 & & & \\
\hline \multicolumn{6}{|c|}{ Pure clay minerals } \\
\hline Ca-Mnt & 26.5 & 43.0 & Ilt-1 & 20.5 & 38.5 \\
\hline Na-Ca-Mnt & 24.5 & 42.0 & Ilt-2 & 19.5 & 36.0 \\
\hline Spe-1 & 37.5 & 62.0 & Hyl & 17.5 & 35.5 \\
\hline Spe-2 & 34.5 & 60.5 & Kln & 18.0 & 31.0 \\
\hline
\end{tabular}

Note: abbreviations are given in Table 1.

and up to 31 - 35 minutes in some samples (Table 1 and Table 2). The dropping duration of temperatures from $65^{\circ} \mathrm{C}$ to $37.5^{\circ} \mathrm{C}$ are range from 34.5 to 55.0 minutes (Figure 2 and Figure 3). Relative to the other samples, samples P-20 and P-20/1 had lower heat dissipation properties may be related to low smectite content. The cooling times of the samples are similar to those of pure illite samples (Table 2). The average time of applying a bandage or plastering on specific areas of the body is 15 - 20 minutes. Therefore, the cooling time from $60^{\circ} \mathrm{C}$ to $37.5^{\circ} \mathrm{C}$ of the prepared pastes must be longer than 15 minutes [2]. The samples studied are suitable for use in therapy as they retain their heat for the required of time.

When cooling kinetics are taken into account, peloids that have been matured at $70^{\circ} \mathrm{C}$ for 24 hours retain their heat for longer than the 20 minutes necessary for therapy, and are therefore suitable for use in this aim. These cooling times were obtained in relatively well isolated conditions. Therefore, in natural applications, the duration of heat dissipation will take low time in the outside, and the cooling time could be 5 to 10 minutes shorter (Figure 2, Figure 3). In this situation, even if the cooling times recorded in the study are reduced by 5 to 10 minutes, the majority of the samples may still be suitable for use. 

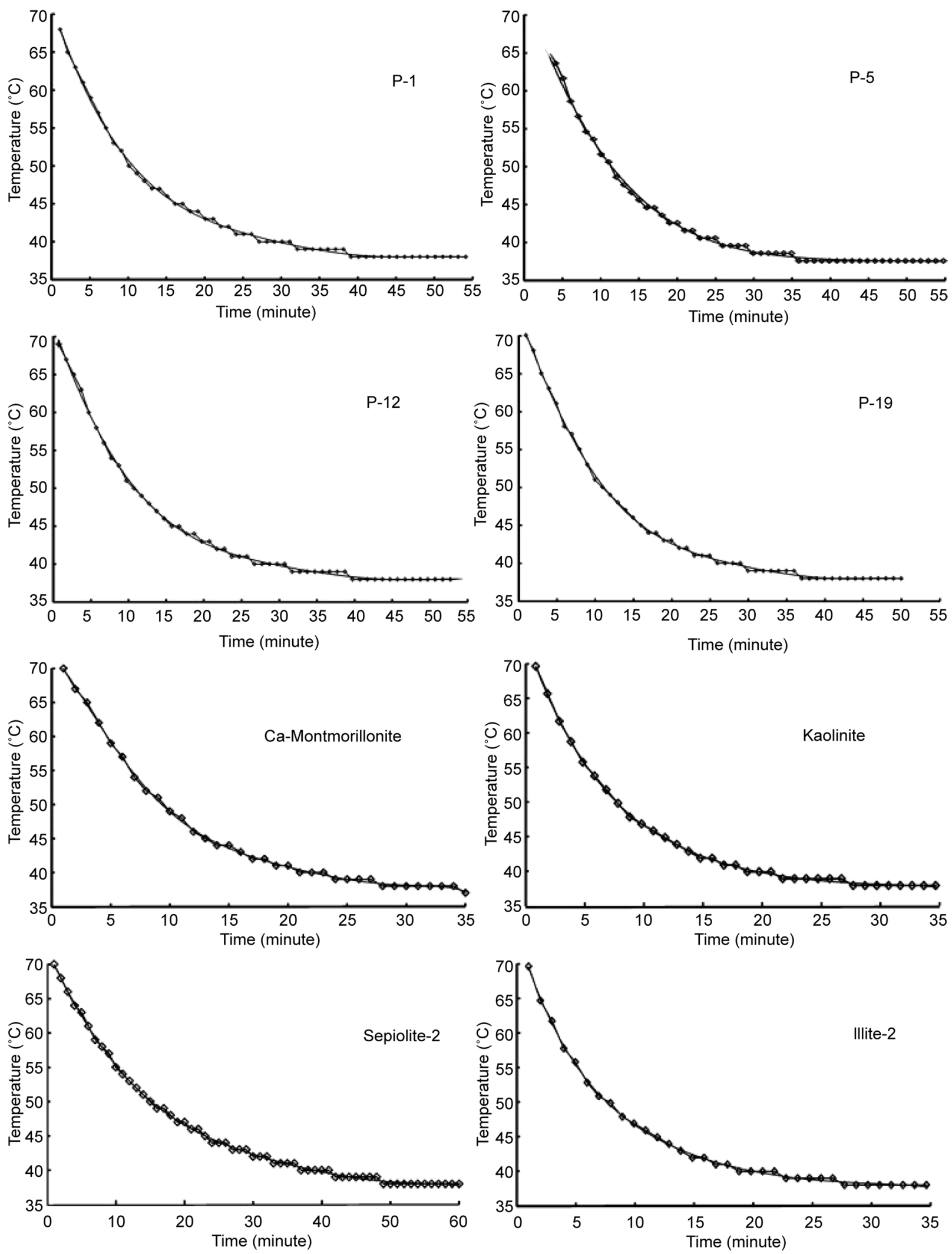

Figure 3. Cooling curves of the peloid- and pure clay mineral-water dispersions. Each rhombus of the black line symbolizes a point of measured temperature data. The black continuous line is the fitted exponential model. 
In thermal therapy, the temperature of the peloid must be over body temperature at least $5^{\circ} \mathrm{C}$ for this reason temperature of the peloids after 15 minutes and dropping duration have been taken into account. The cooling kinetics was determined on the basis of the results, and experimental values were compared to exponential curves by regression analysis to create representative cooling curves (Table 2, Figure 3). The cooling curve is a function of Equation (2).

$$
T=A+B \cdot \mathrm{e}^{-K t}
$$

that stated in many studies [2] [3] [10]. $\mathrm{T}$ is the sample temperature, $\mathrm{A}$ and $\mathrm{B}$ are two constant values related to the bath temperature and the difference between the highest temperature and the bath temperature, $\mathrm{t}$ is the cooling time, and $\mathrm{K}$ is a parameter that depends on the thermal properties of the system. Theoretical cooling kinetics were calculated according the equation given in [10], and cooling curves were drawn depending on the cooling times. The drawn curves matched the experimental graphs. The error rate between the measured values and the drawn curve from the calculated values was determined using the equation. The error rate was also calculated using Equation (3).

$$
e r r=\sqrt{\frac{\sum_{i=1}^{n}\left(T_{c a l, i}-T_{\text {exp }, i}\right)^{2}}{n}}
$$

where $T_{\text {cal }}$ is the temperature resulting from the adjustment, $T_{\exp }$ is the experimentally measured temperature and $\mathrm{n}$ is the number of data recorded by the data collection system [10].

The error of the measurements of the sample P-8, 14, 15, 16/1, 17/1, 18 and 20 was below 0.2 while in samples $\mathrm{P}-5 / 1,7,11,17,20 / 1$ is above 0.3 . The experiments were also carried out on pure clay minerals under the same conditions with the aim of evaluating and comparing the heat dissipation capacity of the peloids (Table 2). According to those results, sepiolite maintains heat for longer, while illite and kaolinite have shorter periods. Also, cooling time from $40^{\circ} \mathrm{C}$ to $37.5^{\circ} \mathrm{C}$ is longer in sepiolite than in other clay minerals. This results show that sepiolite-rich peloids give better results in physical therapy.

DSC was used to analyze the specific heat capacities of the peloid samples. With this method, the energy released during sample heating, cooling or at a constant temperature can be measured. In this method, the difference between the heat absorbed by or emitted from the reference sample is shown in relation to temperature or time. This method was seen as the most suitable method for measuring the heat dissipation of the DSC samples, as the reaction enthalpy is measured defined as [2] [22] [23]. The energy released during the reaction was determined by integrating the DSC peaks, and sample weight was recorded before every reaction to determine specific heat capacity. The specific heat capacities of the two sepiolite samples at 44 and $64^{\circ} \mathrm{C}$ were ranges from 1.72 to 3.32 and 2.62 to $4.63 \mathrm{~J} / \mathrm{g} .{ }^{\circ} \mathrm{C}$. The capacity is low in Ca-montmorillonite and Na-Camontmorillonite samples which are vary from 0.44 to 0.66 and 1.51 and 1.99 at same temperatures, respectively. Illite and halloysite show similar heat values to Ca-montmorillonite. Those values are not close to the results from the peloid samples which 
may be partially related to low smectite content of the peloid.

The specific heat values of peloid samples ranged from 0.61 to $1.44 \mathrm{~J} / \mathrm{g} \cdot{ }^{\circ} \mathrm{C}$. There are strongly positive $\left(r^{2}=0.75\right)$ correlation between cooling rate at temperatures at $65^{\circ} \mathrm{C}$ $40^{\circ} \mathrm{C}$ and specific heat values while moderately positive in pure clay minerals $\left(r^{2}=0.60\right)$ (Figure 4). The pure clay minerals show higher specific heat values than those of the peloid samples, except kaolinite and Ca-montmorillonite (Table 3, Figure 3). Specific heat capacities of pure Ca-montmorillonite sample are lower than $\mathrm{Na}-\mathrm{Ca}$ montmorillonite may be related to water content (Table 3). And also the heat capacities of halloysite is higher than those of kaolinite may also connected with its low water content (Table 3). The similar results were determined on bentonitic clays, specific heat capacity increases with increased clay content [10] [24] [25]. And also Legido [10] who studied on peloids with different compositions of clay minerals and other silicate minerals explained that when peloids composed of smectite and/or sepiolite which have high water contents,

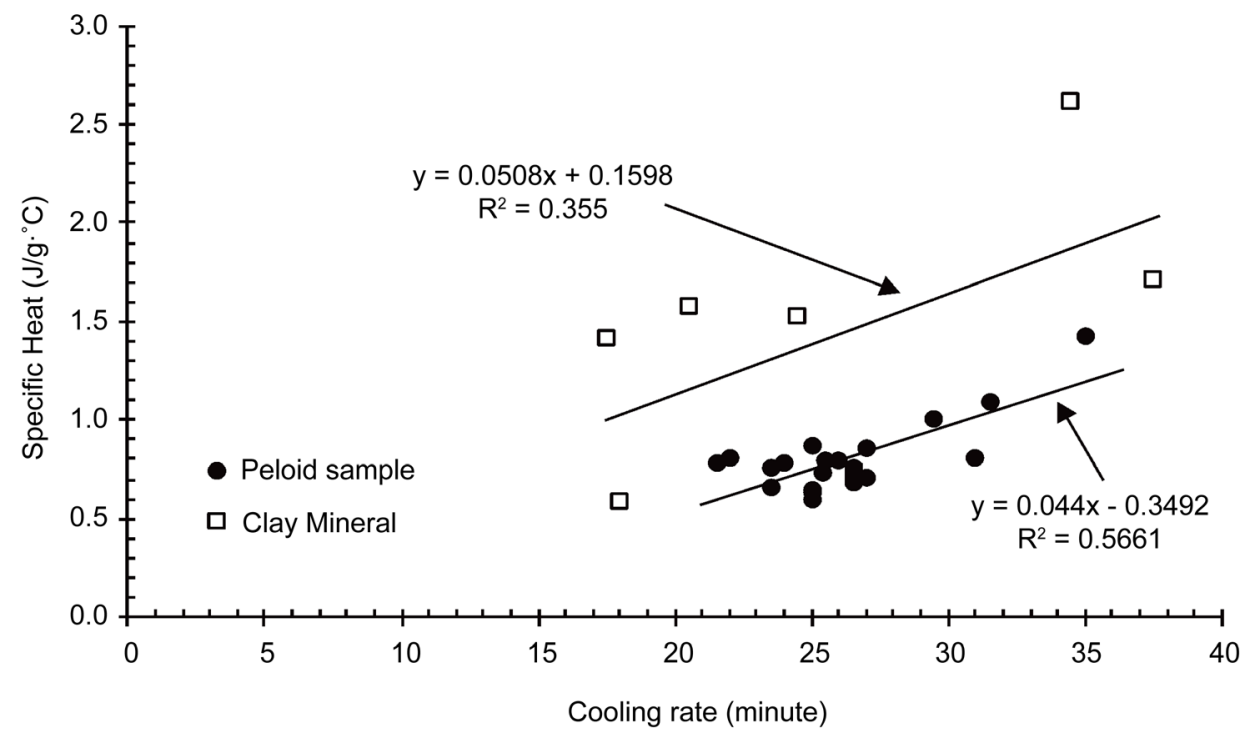

Figure 4. Correlation between cooling rate at temperatures and specific heat values of peloid and clay minerals.

Table 3. Specific heat values at $44^{\circ} \mathrm{C}\left(\mathrm{J} / \mathrm{g} .{ }^{\circ} \mathrm{C}\right)$ of peloids and pure clay minerals.

\begin{tabular}{cccccccccccc}
\hline P-1 & P-1/1 & P-2 & P-5 & P-5/1 & P-6 & P-6/1 & P-6/2 & P-7 & P-8 & P-9 & P-11 \\
\hline 0.87 & 0.77 & 0.79 & 0.67 & 0.68 & 0.70 & 0.65 & 0.60 & 0.79 & 0.66 & 0.74 & 0.66 \\
\hline P-12 & P-13 & P-14 & P-15 & P-16 & P-16/1 & P-16/2 & P-17 & P-18 & P-19 & P-19/1 & P-20 \\
\hline 0.61 & 0.72 & 0.74 & 0.82 & 1.10 & 1.01 & 1.44 & 0.88 & 0.65 & 0.77 & 0.80 & 0.82 \\
\hline P-20/1 & Ca-Mnt & Ca-Na-Mnt & Spe-1 & Spe-2 & Ilt-1 & Hal & Kln & P.O. & M.M. & B.M. & B.C. \\
\hline 0.80 & 0.54 & 1.54 & 1.72 & 2.62 & 1.58 & 1.43 & 0.59 & $1.20-3.55$ & 2.86 & 2.46 & 3.22 \\
\hline
\end{tabular}

Note: MM: Morinje mud [26], B.M: Benetutti mud [6], P.O.: Portuguese clay [29], B.C.: Bentonitic clay [25], abbreviations are given Table 1. 
the specific heat capacity values $(\mathrm{Cp})$ increase. The above authors determined specific heat capacities of $3.48 \mathrm{~J} / \mathrm{g} .{ }^{\circ} \mathrm{C}$ for sepiolite and $3.20 \mathrm{~J} / \mathrm{g} \cdot{ }^{\circ} \mathrm{C}$ for smectite in samples with the same amount of water, and $2.73 \mathrm{~J} / \mathrm{g} .{ }^{\circ} \mathrm{C}$ in a sample of $85 \%$ clay minerals $(49 \%$ kaolinite, $39 \%$ illite and $12 \%$ smectite). Rebelo [2] stated that clays used in pelotherapy should have specific heat capacities greater than $1.00 \mathrm{~J} / \mathrm{g} \cdot{ }^{\circ} \mathrm{C}$ and preferably at least 2.00 $\mathrm{J} / \mathrm{g} \cdot{ }^{\circ} \mathrm{C}$. And also, determined the specific heat values between 1.20 and $1.22 \mathrm{~J} / \mathrm{g} \cdot{ }^{\circ} \mathrm{C}$ and the cooling times ranges from 18 to 19.5 minutes of materials using as peloids. Additionally, specific heat values were found between 2.86 and $2.46 \mathrm{~J} / \mathrm{g} .{ }^{\circ} \mathrm{C}$ in some materials [6] [26]. Besides, Casás [24] found specific heat values 0.85 and $0.89 \mathrm{~J} / \mathrm{g} \cdot{ }^{\circ} \mathrm{C}$ at $20^{\circ} \mathrm{C}$ and $44^{\circ} \mathrm{C}$ temperature for bentonitic mixtures (composed mainly of $55 \% \mathrm{Na}$-saturated smectite, $28 \%$ sepiolite, and $15 \%$ illite), 3.48 and $3.55 \mathrm{~J} / \mathrm{g} .{ }^{\circ} \mathrm{C}$ for $19.9 \%$ bentonite + distilled water, and 2.72 and $2.76 \mathrm{~J} / \mathrm{g} .{ }^{\circ} \mathrm{C}$ for $39.8 \%$ bentonite + sea water. And also Casás [25] found specific heat capacities at $34^{\circ} \mathrm{C}$ and $44^{\circ} \mathrm{C}$ in bentonitic clay mixtures 0.60 and 3.23 and $\mathrm{J} / \mathrm{g} \cdot{ }^{\circ} \mathrm{C}$, respectively, and explained the reason of the values are related to temperature and water content of the clay minerals.

Even though the specific heat capacity values of the current study have similarities with those values determined by Robelo [2], determined capacities are lower and cooling times are longer. Specific heat capacity decreases with increased salinity, and there is a partial increase with an increase in temperature [27]. The specific heat capacities of peloids matured by thermal waters with high chloride content (P-9, 11, and 12) were lower than other samples, except P-9. In peloids with higher clay content in this manner (P-16) specific heat capacity is higher than in other samples. As specific heat capacities of peloids are lower than the pure clay minerals, expect kaolinite and Ca-montmorillonite (Table 3), more energy is required to increase the temperature of these peloids. In other words, to obtain more suitable peloids, materials should be kept for longer in hot waters or prepared from sepiolite-rich or $\mathrm{Na}$-Ca-montmorillonite-rich minerals.

\section{Conclusion}

Heat dissipation capacities of samples collected from thermal spa centers in Turkey at which peloid treatment is carried out were determined ranging between 21.5 and 31.5 minutes for the temperatures from $65^{\circ} \mathrm{C}$ to $40^{\circ} \mathrm{C}$ and these temperatures are suitable for use of peloids in thermal therapy. Samples prepared from pure sepiolites have long and illite and kaolinite have short period of heat dissipation capacity $\left(37^{\circ} \mathrm{C}\right)$ than other pure clays meaning that sepiolite and partially $\mathrm{Na}$-Ca-montmorillonite mixtures are most suitable. Specific heat capacity of peloids was determined to be $0.61-1.44 \mathrm{~J} / \mathrm{g} \cdot{ }^{\circ} \mathrm{C}$ and generally lower than $1.00 \mathrm{~J} / \mathrm{g} .{ }^{\circ} \mathrm{C}$. The determined values are lower than values given in literature for bentonitic clay mixtures and peloids, therefore the peloid samples are weak heat conduction effect. Pure sepiolite samples have partially higher heat dissipation and specific heat $\left(1.72-2.62 \mathrm{~J} / \mathrm{g} .{ }^{\circ} \mathrm{C}\right)$ than those of the illite, halloysite, Na-Camontmorillonite. As a conclusion, especially sepiolite, partially Na-Ca-montmorillonite and illite are the most suitable clay minerals for preparation of peloid pastes than the other clay-rich materials for treatment of chronic pain, such as musculoskeletal, neuro- 
logic problems, cardiopulmonary pathology, etc.

\section{Acknowledgements}

The project was funded by The Scientific and Technological Research Council of Turkey (TÜBİTAK 110Y033) and the Selçuk University Scientific Research Projects support program (BAP 11401045).

\section{References}

[1] Cornejo, J., Hermosin, MC, White, J.L., Barnes, J.R and Hem, S.L. (1983) Role of Ferric iron Oxidation of Hydrocortisone by Sepiolite and Palygorskite. Clays and Clay Minerals, 31, 109-112. http://dx.doi.org/10.1346/CCMN.1983.0310204

[2] Rebelo, M., Viseras, C., López-Galindo, A., Rocha, F. and Ferreira da Silva, E. (2011) Rheological and Thermal Characterization of Peloids Made of Selected Portuguese Geological Materials. Applied Clay Science, 51, 219-227. http://dx.doi.org/10.1016/j.clay.2011.02.018

[3] Carretero, M.I. (2002) Clay minerals and their beneficial effects upon human health: a review. Applied Clay Science, 21, 155-163. http://dx.doi.org/10.1016/S0169-1317(01)00085-0

[4] Nurmikko, T. and Hietaharju, A. (1992) Effect of Exposure to Sauna Heat on Neuropathic and Rheumatoid Pain. Pain, 49, 43-51. http://dx.doi.org/10.1016/0304-3959(92)90186-F

[5] Masuda, A., Hattanmaru, M. and Tei, C. (2006) Repeated Thermal Therapy Improves Outcomes in Patients with Chronic pain. International Congress Series, 1287, 298-303. http://dx.doi.org/10.1016/j.ics.2005.12.039

[6] Cara, S., Cargangiu, G., Padalino, G., Palomba, M. and Tamanini, M. (2000) The Bentonites on Pelotherapy: Chemical, Mineralogical and Technological Properties of Materials from Sardinia Deposits (Italy). Applied Clay Science, 16, 117-124. http://dx.doi.org/10.1016/S0169-1317(99)00049-6

[7] Veniale, F., Barberis, E., Carcangiu, G., Morandi, N., Setti, M., Tamanini, M. and Tessier, D. (2004) Formulation of Muds for Pelotherapy: Effects of "Maturation" by Different Mineral Waters. Applied Clay Science, 25, 135-148. http://dx.doi.org/10.1016/j.clay.2003.10.002

[8] Viseras, C., Aguzzi, C., Cerezo, P. and López-Galindo, A. (2007) Uses of Clay Minerals in Semisolid Health Care and Therapeutic Properties. Applied Clay Science, 36, 37-50. http://dx.doi.org/10.1016/j.clay.2006.07.006

[9] Carretero, M.I. and Pozo, M. (2009) Clay and Non-Clay Minerals in the Pharmaceutical Industry. Part I. Excipients and Medical Applications. Applied Clay Science, 46, 73-80. http://dx.doi.org/10.1016/j.clay.2009.07.017

[10] Legido, J.L., Medina, C., Mourelle, M.L., Carretero, M.I. and Pozo, M. (2007) Comparative Study of the Cooling Rates of Bentonite, Sepiolite and Common Clays for Their Use in Pelotherapy. Applied Clay Science, 36, 148-160. http://dx.doi.org/10.1016/j.clay.2006.06.014

[11] Karakaya, M.Ç., Karakaya, N., Sarığolan, Ş. and Koral, M. (2010) Some Properties of Thermal Muds of Some Spas in Turkey. Applied Clay Science, 48, 531-537. http://dx.doi.org/10.1016/j.clay.2010.02.005

[12] Karakaya, M.Ç., Karakaya, N., Aydın, M.E., Vural, C.H. and Nalbantçılar, M.T. (2013) INVESTIGATION of Properties of Thermal Muds and Waters Using for Therapeutic Purposes. TÜBİTAK Project Number 110Y033.

[13] Karakaya, M.Ç., Doğru, M., Karakaya, N., Vural, C.H., Kuluöztürk, F. and Bal, S.Ş. (2015) Radioactivity Concentrations and Dose Assessments of Therapeutic Peloids from Some Turkish Spas. Clay Minerals, 50, 221-232. http://dx.doi.org/10.1180/claymin.2015.050.2.06 
[14] Çelik, M., Karakaya, N. and Temel, A. (1999) Occurrences of Clay Minerals in Hydrothermally Altered Volcanic Rocks, Eastern Pontides, Turkey. Clays and Clay Minerals, 47, 708717. http://dx.doi.org/10.1346/CCMN.1999.0470604

[15] Karakaya, M.Ç., Karakaya, N. and Temel, A. (2001) Kaolin Occurrences in Erenler Dağ Volcanics, Southwest Konya Province, Turkey. International Geological Review, 43, 711722. http://dx.doi.org/10.1080/00206810109465043

[16] Karakaya, N., Karakaya, M.Ç. and Temel, A. (2011) Mineralogical and Geochemical Characteristics and Genesis of the Sepiolite Deposits at Polatlı Basin (Ankara, Turkey). Clays and Clay Minerals, 59, 286-314. http://dx.doi.org/10.1346/CCMN.2011.0590306

[17] Karakaya, M.Ç., Karakaya, N. and Bakır, S. (2011) Some Properties and Potential Applications of the Na- and Ca-Bentonites of Ordu (N.E. Turkey). Applied Clay Science, 54, 159165. http://dx.doi.org/10.1016/j.clay.2011.08.003

[18] Karakaya, M.Ç. Karakaya, N., Küpeli, Ş. and Yavuz, F. (2012) Properties of Hydrothermal Alteration in the Vicinity of Volcanogenic Massive Sulfide Deposits in Northeast Turkey. Ore Geology Review, 48, 197-224. http://dx.doi.org/10.1016/j.oregeorev.2012.03.007

[19] Gündoğdu, M.N. (1982) Neojen yaşlı Bigadiç sedimanter baseninin jeolojik, mineralojik ve jeokimyasal incelenmesi. PhD, Hacettepe University, Ankara, Turkey.

[20] Temel, A. and Gündoğdu, M.N. (1996) Zeolite Occurrences and Erionite-Mesothelioma Relationship in Cappadocia Region, Central Anatolia, Turkey. Mineralium Deposita, 31, 539-547. http://dx.doi.org/10.1007/BF00196134

[21] Gomes, C. (2002) Argilas Aplicações na Indústria. O Liberal, Câmara de Lobos, Madeira, $338 \mathrm{p}$.

[22] Plante, A., Fernadez, J. and Leifeld, J. (2009) Application of Thermal Analysis Technics in Soil Science. Geoderma, 153, 1-10. http://dx.doi.org/10.1016/j.geoderma.2009.08.016

[23] Rebelo, M., Rocha, F. and Ferreira da Silva, E. (2010) Mineralogical and Physicochemical Characterization of Selected Portuguese Mesozoic-Cenozoic Muddy/Clayey Raw Materials to be Potentially Used as Healing Clays. Clay Minerals, 45, 229-240. http://dx.doi.org/10.1180/claymin.2010.045.2.229

[24] Casás, L.M., Legido, J.L., Pozo, M., Mourelle, L., Plantier, F. and Bessières, D. (2011) Specific Heat of Mixtures of Bentonitic Clay with Sea Water or Distilled Water for Their Use in Thermotherapy. Thermochimica Acta, 524, 68-73.

http://dx.doi.org/10.1016/j.tca.2011.06.016

[25] Casás, L.M., Pozo, M., Gómez, C.P., Pozo, E., Bessières, L.D. and Plantier, F. (2013) Thermal Behavior of Mixtures of Bentonitic Clay and Saline Solutions. Applied Clay Science, 72, 18-25. http://dx.doi.org/10.1016/j.clay.2012.12.009

[26] Mihelčić, G., Kniewald, G., Ivanišević, G., Čepelak, R., Mihelčić, V. and Vdović, N. (2012) Physico-Chemical Characteristics of the Peloid Mud from Morinje Bay (Eastern Adriatic coast, Croatia): Suitability for Use in Balneotherapy. Environmental Geochemical Health, 34, 191-198. http://dx.doi.org/10.1007/s10653-011-9434-y

[27] Millero, F.J. and Pierrot, D. (2005) The Apparent Molal Heat Capacity, Enthalpy, and Free Energy of Seawater Fit to the Pitzer Equations. Marine Chemistry, 94, 81-99. http://dx.doi.org/10.1016/j.marchem.2004.07.011

[28] Whitney, D.L. and Evans, B.W. (2010) Abbreviations for Names of Rock-Forming Minerals. American Mineralogist, 95, 185-187. http://dx.doi.org/10.2138/am.2010.3371

[29] Rebelo, M., Gonçalves, P., Silva, E. and Rocha, F., (2005) Some Portuguese Clay Sediments Used as Raw Materials for Curative Clay Pastes: A Study of Physical and Technological Properties. Acta Geodynamica Geomateralia, 2, 151-155. 